\title{
Rain songs and the observance of the rain cult amongst the Lobedu people of Queen Modjadji ${ }^{1}$
}

\author{
Annekie Joubert \\ Institut für Asien- und Afrikawissenschaften, Humboldt-Universität zu Berlin, Unter den Linden 6, \\ D-10099, Berlin, Germany, and Department of Historical and Heritage Studies, University of Pretoria, \\ Pretoria 0002, South Africa \\ jouberan@staff.hu-berlin.de
}

\begin{abstract}
In this article I will first give a short introduction on the social dynamics and the observance of the rain cult amongst the Lobedu people, who form part of the Northern Sotho branch of the Bantu-speaking peoples of southern Africa. Examples of rain songs that I recorded at the tribal capital of the Lobedu rain queen, Modjadji, will then be discussed. The focus of my discussion in the second part will be on (a) the pre-text, reflecting on the circumstances and background surrounding the performance of rain songs; (b) the main text, namely the transcription of the sung words or verbal utterances of the songs; and (c) the interpretative-text that will encapsulate the composition and literary interpretation of the transcribed performed rain songs.
\end{abstract}

\section{Introduction ${ }^{2}$}

The royal nucleus of the Lobedu descends from one of the Rozwi states that gained prominence in the southern part of the former Karanga empire. ${ }^{3}$ The Lobedu people live in the Limpopo Province below the Drakensberg escarpment near Duiwelskloof. For the past six generations ${ }^{4}$ they have had female rulers, all bearing the dynastic title 'Modjadji', the legendary 'Rain Queen'. According to Hammond-Tooke (1993), the southern Bantu have been living under the rule of various chiefs since at least 800AD. The coming of chieftainship transformed the essential nature of these societies because certain persons were accorded authority to make decisions on behalf of individuals and the group as a whole. According to Hammond-Tooke (1993:65), the only way to safeguard this authority was through ritual, 'by clothing the chieftainship in mystical sections to ensure, as far as possible, compliance with this new political (or governmental) authority'. To achieve the adherence to chieftainship:

- the concept of royal blood was developed, where 'blood' is metaphorically linked to descent and a division created between royalty and commoners

- a sacredness was created around the chief and a mystical link between the person of the chief and the chiefdom as a whole. Hammond-Tooke (1993:65) points out that 'in its extreme form this meant that the health and strength of the ruler could influence the weather, crops and general wellbeing of man and beast'. He mentions Modjadji, the Rain Queen, as an example of this kind of sacredness where it was expected of her to commit ritual suicide after the fourth initiation school of her reign to achieve divine status

- the status of chiefs must be protected by strong medicines to ward off witchcraft, sorcery, assassination and attack from other, antagonistic chiefdoms

- the integrity of chieftainship is ensured by the sacra, possession of which was the ultimate legitimization of the ruler. These could be in the form of sacred heirlooms, medicines or, as in the case of Modjadji, the sacred rainmaking beads, or the sacred rain drums used during rainmaking rituals.

The Lobedu people are surrounded by the Shangaan-Tsonga people to the east, the Pedi to the south, the Venda to the north, and several other tribes to the west. Contact and influx from the Sotho groups in the southeast had a significant influence on Lobedu culture from the mid-eighteenth century onwards. Tsonga refugees, on the other hand, entered the Lobedu area from about 1840 (as recorded in one of the rain songs that will be discussed), but remained segregated subjects within Lobedu territory. An interesting point is that despite the acceptance by the Lobedu of Shangaan-Tsonga elements of material culture, a great divide exists between the two cultural configurations. According to Krige and Krige (1943:313), they have: 
different views as regards sex, morality, different marriage patterns, different conceptions of the hierarchy of age and the position of women, they deal differently with the situation of death, with rainmaking, display, and regimentation, and, whereas the social groupings are totemic among the Lovedu, they are non-totemic among the Shangana-Tonga.

Because of their diplomacy, reputation as rainmakers, and strategic position in the mountains, the Lobedu were the most influential tribe in the Lowveld between the Levubu and the Olifants rivers. The disturbances of the nineteenth century ${ }^{5}$ had only a slight effect on the Lobedu because of their well-protected sanctuary in the mountains. Unlike other chiefs, Modjadji did not depend on an army to maintain peace, stability and political integrity in her territory. She accomplished this through her ritual position as rainmaker and through marriage ties. Her enemies were afraid of attacking her, because the consequences to her attackers were drought and famine.

\section{The Lobedu rain cult}

The rain cult amongst the Lobedu consists of an intricate network of customs with consequences for many aspects of tribal life. The lives and functions of individual members in the tribe are closely intertwined with rain - the indispensable element for human survival. Irregularities in the community, such as the birth of twins, an abortion or a miscarriage, children or animals with deformities, and unrecognized corpses of dogs are thought to have an effect on the rain. ${ }^{6}$ In these cases, the children or animals have to be killed and buried in moist soil, and certain rites have to be performed in order to prevent a terrible drought. ${ }^{7}$ Numerous rain making rituals are also observed for agricultural purposes. Schapera and Goodwin (1953:136) point out that 'various important taboos (e.g. on the cutting of certain trees) must be observed by the whole community during the early part of the rainy season, lest drought, hail, or some similar disaster destroy the young crops'. The Lobedu also possess sacred rainmaking objects such as rain beads, rain horns containing rain medicine, and rain pots filled with holy water - kept in secrecy in a rain hut that is in close proximity to the queen's residence. ${ }^{8}$

It is believed that the Lobedu use the body dirt and skin of deceased queens as part of the rainmaking medicine. ${ }^{9}$ Krige (quoted by Eiselen \& Schapera, 1953:266), describes this process as follows:

On the death of the queen, which is kept secret for a whole year, the body is washed every day and the dirt is made to fall into an earthenware basin. This is done until all the skin comes off, and only then is the chief buried. This skin is put into the rain pots.

The souls of deceased persons become the ancestral spirits of the Lobedu, and are regarded as their most intimate 'gods' (badimo) who act as intermediaries between the living and the spiritual world. According to Eiselen and Schapera (1953:250), the ancestral gods are:

exclusively interested in the affairs of their own family and tribe, and without their help and guidance their living descendants cannot hope to flourish. As long as the moral code is strictly followed, they confer blessings and abundance; but if offended by any breach of custom, they can also send drought, cattle plague, tribal or personal disaster, sickness or death.

Unless sorcery is involved, the misfortunes of a community are 'almost always attributed to the intervention of some offended or neglected ancestor, whose spirit must be propitiated before relief can be expected' (Eiselen \& Schapera, 1953:252). Many of the rainmaking rites have a magical as well as a religious character because magic and religion, according to Eiselen and Schapera (1953:247), are closely inter-related in belief and practice. For example, "when sacrifices are made to the ancestor gods, the meat eaten by the worshippers is often "doctored" with medicines as protection against witchcraft' ${ }^{10}$

When studying the collection of texts documented by Eiselen in the 1920s among various dialect groups such as the Kopa, Pedi and Lobedu, one gets the impression that an assumption does exist among some tribes that a supreme being closely related to the sky exists: 
Ge komelelo e godile vasadi va tla tshela metzi kua levitleng la kgoshi le vzhalwa vzho vontzhi. Vzhalwa vsho ge vo tshelwa levitleng vo vitzhwa metzi. Ge va tshela va volela va re: Modimo o lego godimo a o fe o lego fase metzi (Eiselen, 1923:23).

'When the drought worsens, the women will pour out water and huge quantities of beer on the graves of the chiefs. The beer that is poured on the graves is also called water. As they pour out the beer they utter:

"God, you who are above, give the god below water!"' (Own translation).

Considering the corpus of literature on the Supreme Being (Modimo) in the Sotho religion on the other hand, one becomes aware of the influence caused by encounters with Christian missionaries and the extreme difficulty to 'disentangle the strands of Christian and traditional discourse about Modimo' (Chidester, 1997:278). In a personal interview conducted with the late Queen Modjadji V in 1996, she confessed that her rainmaking powers could be attributed to the grace of the Christian God and the powers of her ancestral gods.

\section{Observance of the Lobedu rain cult}

According to tradition, the Lobedu must observe the rain cult at all times. Either the rain queen or the chief should be approached in times of drought, since the whole tribe acknowledges the queen's ancestors as a source of communal well being and prosperity. ${ }^{11}$ The Lobedu queen is, in the words of Krige and Krige (1943:271):

primarily not a ruler, but a rain-maker, and men rely for their security, not on regimentation, armies, and organization, but on the queen's power to make rain for the people and to withhold rain from its enemies.

Although the queen assumes total responsibility for rain and fertility, it should be pointed out that she always has a rain-doctor (moroka wa pula) who co-operates with her, as all rainmaking rituals have a political character that is linked to the well being of the tribe's polity. For example, as a last resort the rain-doctor will reveal to the queen the forces that prevent her powers from working properly, and remove these forces. Krige and Krige (1943:275) state that "the queen can control rain only "in agreement with her ancestors" who are able, if they wish, to stay her hand just as she herself is able to stay the hands of rain-doctors'. Specially prepared beer has a sacred significance in the observance of the Lobedu rain cult and is regarded as the 'ritual food of the ancestors'. ${ }^{12}$

The queen is not only regarded as the 'transformer of the clouds', but also as the modifier of the seasons and the guarantor of their cyclic regularity. Huskisson (1958:150) points out that the queen is in possession of rain horns (dinaga ja bula) filled with medicine (dithugula). According to Huskisson, the medicine is burnt to produce smoke which rises up in the air to draw and produce the required clouds for rain to fall. ${ }^{13}$ Rain is supposed to fall as long as the horns are placed on the ground, but when they are hung up, the weather clears and the sky becomes dry. The queen's rainmaking ability takes continuous care of her people in times of severe drought as well as in good seasons. According to Lobedu interlocutors, the queen's emotional state affects her rainmaking powers. When she feels upset, sad, dissatisfied or angry, her powers are reduced and her work is less successful.

There are various ways of approaching Queen Modjadji for rain. Councillors whom she holds in high esteem or important relatives may approach her in person; district heads may pay tribute to her (ho lova) in the form of money, cattle or gifts; dancing groups can visit her 'to evoke her pity at the sorrowful sight of people dancing in summer when they ought to be ploughing' (Krige \& Krige, 1943:272). After cooking food for their families, married women would assemble at the royal kraal every morning for up to a week to lova (pay tribute to) their queen with dances to arouse her pity or to bring her joy. ${ }^{14}$ The great hardship that this dancing entails for nursing mothers who have no time to feed their babies is thought to melt the heart of the queen. ${ }^{15}$ The music used during the rain dancing performances consists of lesugu songs, which are also 'sung at the annual harvest ceremony, on the death of important royal people, and at the girls' initiation school' (Krige \& Krige, 1943:273). 
According to the performers of the songs that I documented, a difference exists between multi-functional rain songs and mono-functional or proper rain songs.

- Multi-functional rain songs can include loba songs, which refer to songs that are sung to pay homage to the queen. The verb ho loba/ho lobela means to pay respect, tribute or allegiance to somebody by giving gifts. The following example is used in Ziervogel and Mokgokong's Northern Sotho dictionary (1975:766) to explicate the meaning of the verb: ditšhaba tše ntšhi di lobela pula ga Motšatši (many tribes pay tribute to Modjadji for rain).

- Mono-functional or proper rain songs (lesugu) are usually sung concurrently with the dancing of a special dance called the legobathele. These dances are regarded as the most acclaimed dancing for rain. Krige and Krige (1943:272) describe this dance as follows:

It is more dignified, its movements slower and more stately, and its drumming more subdued than in an ordinary gosha. Only two drums are used, and none but those who have lost at least one parent may perform, and it is begun in the dim light of the dawn before sunrise, when, after a short spell, it stops and is resumed later in the day.

\section{Multi-functional rain song: Nalee nalee valoi! (Nalee nalee witch-doctors!) ${ }^{16}$}

\section{Pre-text: Background information and situational context}

The pre-text of any performance event is as important as the main text and the interpretative text because it preorients the implied reader/audience regarding the aesthetic conventions employed in the performance event, in our examples, the performing of rain songs. The pre-text describes the 'real' situation in which the performance of the rain songs is taking place.

Although this song is called a rain song, according to the interlocutors, it is not used exclusively as such, but is often also used for the purposes of ho lova (to pay homage to the queen). To please her, great councillors, heads of districts or any person who wishes to pay homage to the queen will approach her with gifts ${ }^{17}$ often accompanied by a procession of dancers. As they approach the capital they will sing the lova-songs and chant praises in her honour. The songs are performed exclusively by women.

In January 1996, during a festive occasion at the tribal capital to pay homage to the queen for the good rains, two ladies (Mokadi Molokwane and Mabjalwa Modika) performed Nalee nalee valoi dressed in matching leopard print blouses (dihele) with colourful cloths (dithuku) draped around their shoulders and scarves (methini) around their heads. (The importance of clothing should not be underestimated since it is used to project the social identity of groups. This will be discussed further in the interpretative text.) The women's dance group also performed various other songs and dances dressed in their dancing outfits. The atmosphere was festive and convivial. All dancers were dressed up in their dancing outfits. Drums of all sizes were carried to the Queen's courtyard to accompany the dancers.

\section{Main text: Transcription of verbal utterances ${ }^{18}$}

\section{Nalee nalee valoi!}

Nalee nalee witchdoctors!

(Title of song)

(LS: Lead singer, Mokadi; C: choir, in this case only one person, Mabjalwa)

1. LS: Nalee nalee valoi!

'Nalee nalee witchdoctors!'

2. LS: $O$ nalee nalee nalee!

'O nalee nalee nalee!' 
C: $\quad$ Re ya mosada ga khomo

3. LS: O-wo-wo-ye

'O-wo-wo-ye'

C: $\quad$ Re ya mosada ga khomo

'We are going to the capital with a beast'

4. LS: Mmalo Valovedu ha re khathiana

'Goodness Valovedu we are not many'

C: $\quad$ Re ya mosada ga khomo

'We are going to the capital with a beast'

5. LS: Ee re dadzisidžwe ge merula

'Ee we were inundated with marula trees'

C: $\quad$ Re ya mosada ga khomo

'We are going to the capital with a beast'

6. LS: Mmalo merula va khe ra Vathoga

'Goodness with marula trees we refer to the Tsonga people'

C: $\quad$ Re ya mosada ga khomo

'We are going to the capital with a beast'

7. LS: Ee-we-we-ye,we-we-we

'Ee-we-we-ye, we-we-we'

C: $\quad$ Re ya mosada ga khomo

'We are going to the capital with a beast'

8. LS: O gae Malegudu la Mašwene?

'Where is Malegudu of Mašwene?'

C: $\quad$ Re ya mosada ga khomo

'We are going to the capital with a beast'

9. LS: A-he-he-eh-he-ahee

'A-he-he-eh-he-ahee'

C: $\quad$ Re ya mosada ga khomo

'We are going to the capital with a beast'

10. LS: Thivolla masiisii

'Unleash the scorpions'

C: $\quad$ Re ya mosada ga khomo

'We are going to the capital with a beast'

11. LS: Malegudu melede ya diphephene

'Malegudu the holes of the scorpions'

C: $\quad$ Re ya mosada ga khomo

'We are going to the capital with a beast'

12. LS: Ee-we-wee-ahee

'Ee-we-wee-ahee'

C: $\quad$ Re ya mosada ga khomo

'We are going to the capital with a beast'

13. LS: Ahee-he-ehee-ahee, ahee-he-ehee-ahee, ahee-ahe-ahee-ahee

'Ahee-he-ehee-ahee, ahee-he-ehee-ahee, ahee-ahe-ahee-ahee'

C: $\quad$ Re ya mosada ga khomo

'We are going to the capital with a beast'

14. LS: We-le-wee-ya-hee

'We-le-wee-ya-hee'

C: $\quad$ Re ya mosada ga khomo

'We are going to the capital with a beast' 
15. LS: Mmalo ge ile ge abara ngwe

'Goodness I once wore a leopard skin'

C: $\quad$ Re ya mosada ga khomo

'We are going to the capital with a beast'

16. LS: Le ile le thanola mavala re vone

'Turn inside out your colours let us see'

C: $\quad$ Re ya mosada ga khomo

'We are going to the capital with a beast'

17. LS: Ee-we-we-valoi

'Ee-we-we witchdoctors'

C: $\quad$ Re ya mosada ga khomo

'We are going to the capital with a beast'

18. LS: Ee-we-wee-he

'Ee-we-wee-he'

C: $\quad$ Re ya mosada ga khomo

'We are going to the capital with a beast'

19. LS: Ahee-he-ehee-ahee, ahee-he-ehee-ahee, ahee-he-ehee-ahee

'Ahee-he-ehee-ahee, ahee-he-ehee-ahee, ahee-he-ehee-ahee'

C: $\quad$ Re ya mosada ga khomo

'We are going to the capital with a beast'

20. LS: Ee-we-wee-we, ewe-ewee-we

'Ee-we-wee-we, ewe-ewee-we'

C: $\quad$ Re ya mosada ga khomo

'We are going to the capital with a beast'

21. LS: Ndžu la ga ha le a file ga ho yeba

'My voice is not tired of singing'

C: $\quad$ Re ya mosada ga khomo

'We are going to the capital with a beast'

22. LS: Mmalo ge ile ge abara ngwe Valovedu thanola mavala re vone

'Goodness I once put on a leopard skin Balobedu turn inside out your colours let us see'

C: $\quad$ Re ya mosada ga khomo

'We are going to the capital with a beast'

23. LS: Ee-we-wee-e,ee-we-wee-e

'Ee-we-wee-e, ee-we-wee-e'

C: $\quad$ Re ya mosada ga khomo

'We are going to the capital with a beast'

\section{Interpretative text: Composition and interpretation}

The song is sung in an antiphonal way, with the refrain assigned to a choir and the additional song lines to a soloist. It is interesting to note that the refrain is repeated without interruption while the soloist is singing her lines. The way in which the refrain is repeated plays an important role in creating not only the rhythm of the song, but also the cohesive structure. Although the pattern of the song is conventional, according to the performers it can be improvised by the soloist. The interjections Nalee nalee in the opening two lines are used by the performer to draw attention to the valoi (witchdoctors), which refers here to the Tsonga people who have invaded Lobedu territory. The repetitive refrain Re ya mosada ga khomo (We are going to the capital with a beast) has reference to the abovementioned gifts often taken to the queen to lova her (to pay respect/tribute). 
The composition of the part sung by the soloist is characterized by lines of untranslatable interjections such as ' $\mathrm{O}$ wo-wo-ye' and 'Ee-we-we-ye, we-we-we' (e.g. 3, 7, 9, 12, 13, 14, 17, 18, 19, 20, 23) followed by lines that contain information related to the Lobedu people, the Tsonga people or the performer herself. Line 4 alludes to the size of the Lobedu people (Balobedu we are not many). The Lobedu people are metaphorically inundated by merula, i.e. trees of the species Sclerocaraya birrea (line 5). The referents of the merula are revealed in line 6 as being the Vathoga (Tsonga-speaking people). This metaphor alludes to the large number of Tsonga people who entered the Lobedu area. Krige and Krige (1943:306) point out that 'the greatest single invasion of the lowveld was that of the Shangana-Tonga'. Modjadji's country became crowded as the Lobedus resorted to the hills and the Tsonga people settled in the valleys, surrounding the Lobedu people.

The singer calls on Malegudu ${ }^{19}$ of Mašwene (who was probably in charge of the army) in line 8 to rivolla (unleash) the scorpions (soldiers), (line 10), from their holes (line 11). The singer expresses the subtlest nuances of meaning in this unit as the people metaphorically call on the Queen to instruct Malegudu, the Queen's legate, to unleash the soldiers to act against the possible danger that is inundating the small Lobedu community. The people expect Malegudu, as an important councillor, to go to Queen Modjadji to appease her, and to plead for her advice and protection.

Lines 15, 16,21 and 22 relate to the physical appearance and action of the dancing procession. They are dressed in their dancing clothes (ge abara ngwe), 'I wear a leopard skin'. This expression has reference to the dancers' clothes that have a leopard skin print. A leopard skin usually forms part of the regalia worn by chiefs and serves to indicate their power and status. A chief is often called moaparankwe (the one who wears the leopard) in Northern Sotho. During the inauguration of the late Queen Modjadji V in October 1982, Dr. C.N. Phathudi, former chief minister of the Lebowa homeland, acknowledged her reign by placing a leopard skin around her shoulders. The dancing procession honours the Queen in this way, not only by their actions, but also with their appearance. The wearing of identical clothes also projects a sense of cohesion through symbolic identification as being of Lobedu origin, thereby articulating their heritage. The people address the Queen directly in line 16 by asking her to show them her true colours. They expect the Queen, by this request, to show her true leadership and power in combating their enemy, the Vathoga, to whom metaphoric reference is made. In line 21, the singer announces that her voice is not tired of singing, thereby indicating her dedication and perseverance in paying homage to her Queen.

The song's message can be manifold since the singer addresses the witchdoctors in the first line and mentions them again in line 17. When utilized as a rain song, it can be interpreted as a warning to the witchdoctors not to tie the Queen's hands, preventing her from producing rain. When the song is utilized as a lova song, as in this instance, the 'witchdoctors', can also refer metaphorically to the enemies of the Lobedu people, i.e. the Tsongas. This song can therefore be interpreted as an admonition to witchdoctors and enemies, as well as a proclamation of the power of the Queen and her abilities not only to produce rain for her people, but also to overpower her enemies and protect her people.

\section{Mono-functional (proper) rain songs: Kherobe phanyo (The stiff thigh-bone); Mmadikha- diana (Mmadikhadiana); O yoo Magobe yoo dala (O yoo Magobe yoo the famine) ${ }^{20}$}

\section{Pre-text: Background information and situational context}

The following three songs are regarded by the interlocutors as proper rain songs. Since their basic structures are very short and simple, comprising in some cases only two song lines, they will be discussed together.

The setting forms one of the defining criteria for proper rain songs, since they are performed in a special place (courtyard of the queen), and at a specific time (in times of drought). The rarity of these performances makes it very difficult to see or record them in their real situational contexts. The examples that are to be discussed were not 
performed in a proper situational context i.e. the courtyard of the queen, but at the request of the late Prof. Louis Louwrens and myself, in the courtyard of one of the performers. The group of old people did not dance the special legobathhele dance, but only sang the verbal utterances of the rain songs (lesugu songs).

Certain restrictions also apply to age and gender. While women normally perform the songs, a man did, however, participate in this performance, as it was not in its proper situational context. The verbal texts are fixed, and are to be performed with no addition, modification, or improvisation while being delivered. The lyrics are therefore brief and stereotyped. The songs are all characterized by rhythmic repetition that forms an almost magical formula. The meaning and function of rain songs constitute an important component in the ritual and ceremonial life of the Lobedu people. This unique sub-genre is undoubtedly a form of communication employed by the community to effect change through worship, honour and invocation in times of drought and difficulties.

Main text, song one: Transcription of verbal utterances

\section{Kherobe phanyo}

The stiff thighbone

(Title of song)

1. LS: Na šago le khe fa le a le vona na vanna wee?

'You men, don't you see this land is dying?'

C: $\quad$ Vanna wee, kherobe phanyo

'You men, the stiff thighbone'

2. LS: Aee, šago le a fa, le a le vona na vanna wee?

'Aee, the land is dying, do you see it you men?'

C: $\quad$ Vanna wee, kherobe phanyo

'You men, the stiff thighbone'

\section{Interpretative text, song one: Composition and interpretation}

The women, who are the agriculturists in the Lobedu culture, address the Lobedu men in this song. The women ask the men if they have noticed the suffering caused by the intense drought. This song is actually a metaphor in itself since according to the interlocutors, it contains an embedded directive to men to keep the graveyards of the ancestors intact, in other words to look after the dead in a physical way by keeping the graves neat, and spiritually by taking offerings to the ancestral shrines..$^{21}$

\section{Main text, song two: Transcription of verbal utterances}

\section{Mmadikhadiana \\ Mmadikhadiana}

(Title of song)

1. LS: Ge Mmadikhadiana velevedana wee-yee

'It is Mmadikhadiana velevedana wee-yee'

C: $\quad$ Re volaiswa ke Mmadikhadiana

'We are burdened by Mmadikhadiana'

\section{Interpretative text, song two: Composition and interpretation}

The song is repeated several times and refers to Mmadikhadiana, the suspect (witchdoctor) who burdens (kills) the people through drought. His name is derived from his witchdoctor's outfit: dikhadiana (pieces of animal skin) attached to his body, and velevedana (shreds of animal skin), hanging down from his loins. ${ }^{22}$ 
Main text, song three: Transcription of verbal utterances

\section{O yoo Magobe yoo dala}

O yoo Magobe yoo the famine

(Title of song)

1. LS: O yoo Magobe yoo dala

'O yoo Magobe yoo the famine'

C: $\quad$ O yoo Magobe yoo dala

'O yoo Magobe yoo the famine'

2. LS: O yoo Magobe dala ya matšhona

'O yoo Magobe the severe famine'

C: $\quad$ O yoo Magobe yoo dala

'O yoo Magobe yoo the famine'

3. LS: O yoo Magobe dala ya a vava

'O yoo Magobe the famine is terrible'

C: $\quad$ O yoo Magobe yoo dala

'O yoo Magobe yoo the famine'

4. LS: O yoo Magobe yoo dala

'O yoo Magobe yoo the famine'

C: $\quad$ O yoo Magobe yoo dala

'O yoo Magobe yoo the famine'

\section{Interpretative text, song three: Composition and interpretation}

The title of the song Magobe, is derived from the verb stem -khobela, (to ask), alluding to the underlying tone of invocation or prayer. The word, Magobe, refers metaphorically to the queen, as the one whom the people approach with their supplications. The antiphonal form of this song is expressively used to indicate the plight of all the people, the lead singer (LS) or soloist, as well as the choir (C). The song makes mention of the matšhona (severe) famine, which must have had such a dramatic effect on the Lobedu people that it is still remembered today. Like the other proper rain songs, this song is only sung by women in the courtyard of the queen. The women will, after a whole day of dancing and exhaustion, move to the centre of the dancing circle, throw themselves to the ground and whirl around, acting out convulsive movements and simultaneously undressing themselves. These acts, together with the repetitive form of the song, are metaphorically used to dramatize their desperation, and to evoke the Queen's pity to stop their suffering by sending much needed rain.

\section{Conclusion}

The observance of the rain cult and the performance of rain songs are, as could be concluded from the discussion, of vital importance amongst the Lobedu. Multi-functional rain songs (lova songs) are mainly sung to pay homage to the queen and to proclaim her power as rain maker. The songs are less structured and can be performed on different occasions. Mono-functional rain songs (lesugu songs) are regarded as proper rain songs that are usually accompanied by the special legobathele dance. Their lyrics are stereotyped with a magical rhythmic formula. The songs can only be performed at special designated places and specific times, such as drought, famine or calamity. Gender and age restrictions also apply to the singing of proper rain songs.

The performing of rain rituals and rain songs explicate various functions within Lobedu society. The link between the queen and her royal ancestry, who are regarded as divine gods (badimo), ennoble her not only as a mystical figure who acts within a cosmic and moral order as intermediary between the tribe and the ancestral gods, but also as political ruler through her ritual position as rainmaker. Her status and authority require adherence and loyalty 
from her subjects and commands respect from other tribes in the region whose dependency on rain and prosperity is in her hands. The control of rainmaking and the possession of the rainmaking sacra bolster the queen's political authority and strengthen the Lobedu's political position in the region. The execution of rain rituals also has some sociological functions.

The equilibrium and unity in the community is maintained through the performances of life cycle rites. The rituals charter the agricultural year and the regularity of seasons as well as the forbearing of breaches of traditional laws or taboos by members in the community. Life is permeated by events that find expression in various performances that range, for example, from the expression of elation and thanksgiving in times of good rain to rituals of entreaty in times of drought and famine. The community's devotion to these rituals denotes a religious function that could be regarded as a way of communication through worship and invocation - a form of prayer or divine fidelity towards the ancestors in times of hardship. In her article 'A Lovedu prayer - The light it throws on the ancestor cult' (1954), Eileen Krige explains the relationship between the queen and the ancestors (badimo) as being one of human warmth and parental authority. The morally grounded relationship between the queen, the tribe and the ancestors instils a sense of security within the community and keeps the ancestor cult and rain rituals alive and pertinent, even in times of social and environmental change.

\section{Notes}

1. My thanks go to the late Prof. Louis Louwrens who inspired me over many years through his expert knowledge of Northern Sotho. He accompanied me in November 2001 on my last field research trip to Queen Modjadji. His expertise in the Lobedu dialect as well as his boundless and stimulating comments significantly enriched my thinking and guided me not only in the transcription of the rain songs, but also on the trails of interpretation. I fondly dedicate this article to him.

2. Irregularities in terms of the spelling of words e.g. lova/loba, Lovedu/Lobedu may be attributed to differences between the Lobedu dialect and standard Northern Sotho.

3. Davison (1979:8); Alpers (1970:203-220); Abraham (1961:211).

4. Webster (2009:9).

5. The ravages by Moselekatse in the south, southwest and west (1826-1830); Sekwati's raids (1826-1830); the rise of the Pedi under Thulare (1800-1824); turmoil and displacement of the Tonga, culminating in the exploits of Albasini (1840-1860), and the invasions of the Swazi (1857-1860).

6. Huskisson (1958:148-152).

7. Krige (1953:108).

8. Rain hut and objects were pointed out to me by Mahatole Mathekga, tribal capital, Modjadji, 9 November 2001.

9. Personal communication from Dr Peter Boshego, University of South Africa, 11 September 2001.

10. Reference is made in the song Mmadikhadiana, to the suspect witchdoctor who burdens (kills) the people through drought.

11. See Eiselen and Schapera (1953:251).

12. Chidester (1997:279).

13. See documentation: Kgoshi e nesha pula (The chief makes rain) by Eiselen (1923:23-24 and 63-64).

14. Personal communication with Mahatole Mathekga, Mabjalwa Ralekhokho and Maphethola Ntshaupa, tribal capital, Modjadji, 9 November 2001.

15. Krige and Krige (1943:272)

16. See Joubert (2004:331-341).

17. Personal communication with Mahatole Mathekga, Mabjalwa Ralekhokho and Maphethola Ntshaupa, tribal capital, Modjadji, 9 November 2001.

18. The texts (verbal utterances) of the rain songs are transcribed in Lobedu, the Northern Sotho dialect in which they were performed and recorded, and not in standard Northern Sotho. 
19. The name Malegudu often appears in the oral art of the Lobedu people. He was, according to Krige and Krige (1943:173), the elder brother of Modjadji I, and a very influential councillor. In this song, the name Malegudu does not necessarily refer to the brother of Modjadji I, but has, because of his importance, acquired a general status that could be transferred to any significant person.

20. See Joubert (2004:341-347).

21. It is widely believed that the air that escapes from weathered graves and eroded coffins causes a stir of wind, which keeps the rain away. The men are therefore instructed to repair the graves of the ancestors. Personal communication from Mahatole Mathekga and Mabjalwa Modika, Modjadji tribal capital, Bolobedu, 9 November 2001.

22. Personal communication from Mahotole Mathekga, Modjadji tribal capital, Bolobedu, January 1996.

\section{References}

Abraham, D.P. 1961. Maramuca: An exercise in the combined use of Portuguese records and oral tradition. Journal of African History 2(2):211-225.

Alpers, E.A. 1970. Dynasties of the Mutapa-Roswi complex. Journal of African History 11(2):203-220.

Chidester, D. 1997. African traditional religion in South Africa. Westport: Greenwood Press.

Davison, P. 1979. The material culture of the Lobedu: A museum and field study. Unpublished master's dissertation. Stellenbosch: University of Stellenbosch.

Eiselen, W. 1923. Nuwe Sesoeto tekste van volkekundige belang. Kaapstad: Nasionale Pers, Beperk.

Eiselen, W.M. \& Schapera, I. 1953. Religious beliefs and practices, in The Bantu-speaking tribes of South Africa, edited by I. Schapera. Cape Town: Maskew Miller Limited:247-270.

Hammond-Tooke, D. 1993. The roots of black South Africa. Johannesburg: Jonathan Ball Publishers.

Huskisson, Y. 1958. The social and ceremonial music of the Pedi. Unpublished doctoral thesis. Johannesburg: University of the Witwatersrand.

Joubert, A. 2004. The power of performance. Berlin: Mouton de Gruyter.

Krige, E.J. 1953. Individual development, in The Bantu-speaking tribes of South Africa, edited by I. Schapera. Cape Town: Maskew Miller Limited:95-118.

Krige, E.J. 1954. A Lovedu prayer - The light it throws on the ancestor cult. African Studies 13:91-97.

Krige, E.J. \& Krige, J.D. 1943. The realm of a Rain-Queen. London: Oxford University Press.

Schapera, I. \& Goodwin, A.J.H. 1953. Work and wealth, in The Bantu-speaking tribes of South Africa, edited by I. Schapera. Cape Town: Maskew Miller Limited:131-171.

Webster, R. 2009. The details in the devil of the kloof. Sunday Times. 19 July.

Ziervogel, D. \& Mokgokong, P.C. 1975. Comprehensive Northern Sotho dictionary. Pretoria: J.L. van Schaik Ltd. 